\title{
WYBRANE ASPEKTY UDZIALU ORGANIZACJI SPOLECZNEJ W POSTĘPOWANIACH DOTYCZĄCYCH INDYWIDUALNYCH SPRAW STUDENTÓW I DOKTORANTÓW
}

\begin{abstract}
Streszczenie. Celem niniejszego opracowania jest przybliżenie problematyki udziału organizacji społecznej w postępowaniach administracyjnych dotyczących spraw studentów i doktorantów, przy czym rozważania dotyczące tego zagadnienia zostały ograniczone do ściśle wybranych i opisanych w jego treści podmiotów. Ich wybór został zdeterminowany specyfiką spraw studencko-doktoranckich oraz całej sfery szkolnictwa wyższego, które korzysta z konstytucyjnie gwarantowanej autonomii. Omówiono przy tym ich charakter prawny. Wskazano również na przysługujące im uprawnienia procesowe, mające swoje źródło w przepisach postępowania administracyjnego, które w omawianej kategorii spraw stosuje się odpowiednio, zwracając przy tym uwagę na możliwe problemy wynikające z niedoskonałości obowiązujących w tym zakresie unormowań prawnych.

Słowa kluczowe: postępowanie administracyjne, szkolnictwo wyższe, sprawy studentów i doktorantów, organizacja społeczna, samorząd studentów i doktorantów, rzecznicy praw studentów i doktorantów.
\end{abstract}

Problematyka udziału podmiotów na prawach strony w postępowaniu administracyjnym, czyli podmiotów, którym prawo procesowe przyznaje procesowe uprawnienia strony, mimo że nie są one formalnie stroną toczącego się postępowania, wielokrotnie stanowiła przedmiot analizy przedstawicieli nauki prawa i postępowania administracyjnego, stając się punktem rozważań licznych opracowań naukowych, komentarzowych oraz rozdziałów w podręcznikach akademickich ${ }^{1}$. Możliwość występowania w takim właśnie charakterze przepisy Kodeksu postępowania administracyjnego ${ }^{2}$ przewidują w odniesieniu do prokuratora, Rzecznika

* Uniwersytet Łódzki, Wydział Prawa i Administracji, Katedra Polskiego Postępowania Administracyjnego.

${ }^{1}$ Por. M. Daszkiewicz, Uwagi na tle udzialu prokuratora $w$ postępowaniu przed organem II instancji, „Administracja. Teoria - Dydaktyka - Praktyka” 2008, nr 4, s. 160-177; B. Adamiak, J. Borkowski, Postepowanie administracyjne i sadowoadministracyjne, Wolters Kluwer, Warszawa 2014, s. 144-151; K. Wąsowski, [w:] M. Wierzbowski, A. Wiktorowska (red.), Kodeks postepowania administracyjnego. Komentarz, C.H. Beck, Warszawa 2011, s. 171-173.

${ }^{2}$ Ustawa z 14.06.1960 r. - Kodeks postępowania administracyjnego, t.j. Dz. U. 2016, poz. 23 , dalej: KPA. 
Praw Obywatelskich oraz organizacji społecznej. $Z$ uwagi jednak na zasadniczy cel tego opracowania, zakreślony bezpośrednio w jego tytule, dalsze rozważania będą koncentrowały się wyłącznie wokół ostatniego z wymienionych podmiotów, czyli organizacji społecznej. Ponadto już na wstępie należy podkreślić, że analiza problematyki jej udziału w postępowaniach administracyjnych dotyczących indywidualnych spraw studentów i doktorantów dotyczyć będzie szczególnych podmiotów reprezentujących prawa i interesy przedstawicieli wspomnianych grup społeczności akademickiej, tj. samorządu studenckiego i samorządu doktorantów, Parlamentu Studentów Rzeczypospolitej Polskiej (PSRP), Krajowej Reprezentacji Doktorantów (KRD) oraz rzeczników praw: studentów oraz doktorantów. Ich status prawny nie jest bowiem w pełni jasny, przez co w praktyce nie wiadomo, czy w ogóle dopuszczalne jest przypisanie im statusu organizacji społecznej w rozumieniu przepisów KPA, czy może należałoby taką ewentualność wykluczyć3.

Przepis art. $5 \S 2$ pkt 5 KPA definiuje organizacje społeczne jako organizacje zawodowe, samorządowe, spółdzielcze i inne organizacje społeczne, nie wskazując jednak uniwersalnego kompleksu cech właściwych tym podmiotom, na co zresztą niejednokrotnie zwracano uwagę $\mathrm{w}$ piśmiennictwie ${ }^{4}$. Jednym $\mathrm{z}$ najpoważniejszych i najczęściej wskazywanych w literaturze mankamentów jest również brak normatywnie określonej relacji między pojęciami organizacji społecznej oraz organizacji pozarządowej ${ }^{5}$. Wprawdzie także ostatnie z wymienionych pojęć nie unika krytyki przedstawicieli doktryny ${ }^{6}$, lecz mimo to uznaje się je za trafniejsze, bowiem odbiegając znacząco od kodeksowej formuły organizacji społecznej, lepiej odzwierciedla tendencje rozwoju języka prawnego ${ }^{7}$. Osią innego, równie intensywnego dyskursu była kwestia przyznania statusu organizacji społecznej fundacjom ${ }^{8}$. Wydaje się jed-

3 Trzeba nadmienić, że podstawą rozważań o udziale organizacji społecznej w indywidualnych sprawach studentów i doktorantów jest treść art. 207 ustawy z 27.07.2005 r. - Prawo o szkolnictwie wyższym (t.j. Dz. U. 2012, poz. 572 ze zm., dalej: PrSzkolWyż) przewidującego, że w tej kategorii spraw przepisy KPA stosuje się odpowiednio.

${ }^{4}$ A. Gronkiewicz, Kilka uwag na temat udziału organizacji społecznej (pozarządowej) w postępowaniu administracyjnym i postępowaniu sądowoadministracyjnym, [w:] J. Niczyporuk (red.), Kodyfikacja postępowania administracyjnego na 50-lecie k.p.a., Wydawnictwo WSPA, Lublin 2010, s. 203 oraz eadem, Organizacja społeczna w ogólnym postępowaniu administracyjnym, Lex a Wolters Kluwer business, Warszawa 2012.

${ }^{5}$ Pojęciem tym posługuje się m.in. ustawa z 24.04.2003 r. o działalności pożytku publicznego i wolontariacie (t.j. Dz. U. 2014, poz. 1118 ze zm.). Por. także: M. Grzeszczuk, Z problematyki form udziału organizacji społecznych w postępowaniu administracyjnym, [w:] J. Niczyporuk (red.), op. cit., s. 218-223.

${ }^{6} \mathrm{Za}$ : ibidem.

${ }^{7}$ Por. A. Skoczylas, M. Swora, Organizacje społeczne (pozarzadowe) w postepowaniu administracyjnym i sądowoadministracyjnym, „Administracja. Teoria - Dydaktyka - Praktyka” 2006, nr 3, s. 13-36.

${ }^{8}$ Por. m.in.: wyrok NSA z 13.11.2002 r., IV SA 2680/00, niepubl.; wyrok NSA z 30.10.2003 r., IV SA 1087/01, niepubl.; uchwała NSA z 12.12.2005 r., II OPS 4/05 oraz glosy do niej autorstwa: J. P. Tarno, ZNSA 2006, nr 1, s. 150-157; J. Repela, ZNSA 2006, nr 1, s. 158-164; I. Skrzydło-Niż- 
nak, że ze względu na znikome znaczenie tej problematyki dla niniejszego opracowania można ją pominąć.

Odnosząc powyższe uwagi do wcześniej wymienionych podmiotów, nadal można mieć wątpliwości, czy w świetle przepisów KPA spełniają one wymagania odnoszące się do organizacji społecznej, mogąc działać w takiej roli w indywidualnych sprawach studentów i doktorantów. Dla ich wyjaśnienia konieczne wydaje się więc głębsze sięgnięcie do dorobku doktryny.

W opinii E. Smoktunowicza zawartą w KPA definicję organizacji społecznej wyróżnia otwarty charakter, dlatego obejmuje ona wszystkie trwałe zrzeszenia osób fizycznych oraz prawnych, niewchodzące w skład aparatu państwowego i niebędące spółkami prywatnymi ${ }^{9}$. Zdaniem tego autora udział organizacji społecznej w postępowaniu administracyjnym służy umacnianiu demokracji, a to uzasadnia potrzebę rozszerzającego (z uwzględnieniem wykładni funkcjonalnej) interpretowania wszelkich niejasności wyłaniających się na tle omawianego pojęcia ${ }^{10}$.

Powyższy pogląd można w pełni odnieść do Parlamentu Studentów RP, Krajowej Reprezentacji Doktorantów oraz odpowiednich samorządów, przyznając im potencjalnie przymiot organizacji społecznej. Jest on natomiast nieadekwatny w stosunku do rzeczników praw: studentów i doktorantów, w przypadku których trudno mówić o zrzeszeniowym charakterze. Rozwiązaniem pozwalającym uniknąć wykluczenia uczestniczenia wspomnianych rzeczników w charakterze podmiotu na prawach strony, mogłoby być zastosowanie na zasadzie analogii przepisów KPA dotyczących podobnego udziału Rzecznika Praw Obywatelskich. Wnioskowanie per analogia w prawie administracyjnym budzi jednak poważne wątpliwości i może być postrzegane jako czynnik zagrażający pewności obrotu prawnego ${ }^{11}$. Dlatego alternatywnej możliwości można by potencjalnie upatrywać w instytucji pełnomocnictwa.

Powszechnie obowiązujące akty normatywne nie regulują kwestii powoływania, a tym bardziej funkcjonowania ani rzecznika praw studenta, ani jego odpowiednika pracującego na rzecz doktorantów. O zakresie ich działania przesądzają

nik, „Przegląd Sejmowy” 2006, nr 2, s. 128-139; A. Zieliński, PiP 2006, nr 8, s. 122-126; T. Bąkowski, „Gdańskie Studia Prawnicze - Przegląd Orzecznictwa” 2007, nr 2, s. 53-59.

${ }^{9}$ E. Smoktunowicz, Udział organizacji społecznej w postępowaniu administracyjnym dotyczacym innej osoby (art. 31 k.p.a.), [w:] Z. Duniewska, M. Górski, M. Stahl (red.), Procedura administracyjna wobec wyzwań wspótczesności, Wydawnictwo Uniwersytetu Łódzkiego, Łódź 2004, s. 194-195.

${ }^{10}$ Ibidem.

${ }^{11}$ Szerzej problematyką analogii w prawie administracyjnym zajmował się m.in. E. Smoktunowicz. Autor ten należał do grona zwolenników jej stosowania jednak tylko w obszarze przepisów obojętnych z punktu widzenia praw i obowiązków jednostki. Por. idem, Analogia w prawie administracyjnym, Państwowe Wydawnictwo Naukowe, Warszawa 1970. Z kolei orzecznictwo sądów administracyjnych stoi na stanowisku, iż z uwagi na to, że przepisy prawa administracyjnego mają charakter ius cogens, a organy władzy publicznej działają na podstawie i w granicach prawa, analogia jako metoda wykładni tej gałęzi prawa jest niedopuszczalna. Mogłaby ona prowadzić do tworzenia nieprzewidzianych prawem regulacji wpływających na prawa jednostki. Zob. wyrok NSA z dnia 15.01.2013 r., II OSK 2451/12, niepubl. 
wyłącznie przepisy statutów PSRP oraz KRD, w strukturach których przewidziano miejsce dla poszczególnych rzeczników.

Zgodnie z postanowieniami statutu PSRP ${ }^{12}$ Rzecznik Praw Studentów jest organem Parlamentu ${ }^{13}$ powołanym na dwuletnią kadencję do obrony praw studenckich, działającym w formach przewidzianych statutem, w tym m.in. poprzez udział w charakterze uczestnika w postępowaniach przed organami władzy publicznej, a także przed sądami i trybunałami ${ }^{14}$. Należy ponadto zaznaczyć, że Parlament stanowi oficjalne przedstawicielstwo uczelnianych samorządów studenckich i z mocy prawa został wyposażony w osobowość prawną ${ }^{15}$ oraz stosuje się do niego odpowiednio niektóre przepisy ustawy Prawo o stowarzyszeniach ${ }^{16}$. Tym samym Rzecznik Praw Studentów nie jest podmiotem autonomicznym w stosunku do PSRP, lecz w określonej kategorii spraw działa w jego imieniu. Innymi słowy Rzecznik Praw Studentów pełni rolę statutowego przedstawiciela Parlamentu, co de facto odpowiada przyjętemu w KPA modelowi działania organizacji społecznych poprzez ustawowych lub właśnie statutowych przedstawicieli. Wniosek taki wynika z analizy art. $31 \S 3$ oraz $30 \S 3$ KPA. Pierwszy z powołanych przepisów stanowi, iż organizacja społeczna uczestniczy w postępowaniu na prawach strony, kolejny zaś wskazuje, że strony niebędące osobami fizycznymi działają przez swych ustawowych i statutowych przedstawicieli. Wobec powyższego nie powinno budzić wątpliwości, że skoro organizacja społeczna ma w omawianych sprawach działać na prawach strony, a jednocześnie z natury swej nie jest osobą fizyczną, to sposób jej działania powinien być właściwy dla stron niebędących tego rodzaju osobami.

Podobną pozycję prawną co Rzecznik Praw Studentów posiada Rzecznik Praw Doktorantów, który na mocy $\S 3$ ust. 1 pkt 5 oraz $\S 22$ Statutu KRD jest organem tej organizacji stojącym na straży praw doktoranta określonych w obowiązujących aktach normatywnych, umocowanym z jej ramienia m.in. do występowania w imieniu konkretnych doktorantów wobec władz uczelni oraz podejmowania mediacji i działań wyjaśniających $\mathrm{w}$ sprawach indywidualnych ${ }^{17}$.

${ }_{12}$ Statut Parlamentu Studentów Rzeczypospolitej Polskiej przyjęty uchwałą Zjazdu PSPR z 26.10.2013 r., http://bip.psrp.org.pl/uploads/Statut\%20PSRP.pdf (dostęp: 30.04.2015). Szerzej o PSRP m.in.: T. Brzezicki, Ustrój szkolnictwa wyższego w Polsce, Wydawnictwo „Dom Organizatora”, Toruń 2010, s. 236-242 oraz Ł. Błąd, [w:] S. Waltoś, A. Rozmus (red.), Szkolnictwo wyższe w Polsce. Ustrój-prawo - organizacja, Wydawnictwo Wyższej Szkoły Informatyki i Zarządzania z siedzibą w Rzeszowie, Rzeszów 2009, s. 384-385.

${ }^{13}$ Por. $§ 4$ pkt 6 Statutu PSRP.

${ }^{14}$ Por. rozdział IV (§ 33-34) Statutu PSRP. Zgodnie z tymi przepisami pozostałymi formami działania Rzecznika jest: podejmowanie interwencji w sprawach związanych ze studiami wyższymi, organizowanie kampanii informacyjnych, szkoleń, konferencji oraz debat, a także wnoszenie skarg na decyzje uczelni, która w jakikolwiek sposób dotyka studentów.

15 Por. art. 203 oraz art. 203a ust. 1 i 2 PrSzkolWyż.

${ }^{16}$ Ustawa z 7.04.1989 r. - Prawo o stowarzyszeniach (t.j. Dz. U. 2015, poz. 1393).

${ }^{17}$ Aktualnie obowiązujący Statut Krajowej Reprezentacji Doktorantów stanowi załącznik nr 1 do uchwały nr 4 Nadzwyczajnego Zjazdu Delegatów w Warszawie z 4.05.2014 r., www.krd.org.pl (dostęp: 7.05.2015). 
Warto jednak zauważyć, że jeszcze do niedawna status Rzecznika Prawa Doktorantów nie był tak jednoznaczny, ponieważ wcześniej obowiązujący Statut KRD w ogóle nie sankcjonował istnienia takiego podmiotu, przez co działał on niejako obok struktur tej organizacji ${ }^{18}$. Niekoniecznie musiało to wykluczać jego udział w postępowaniach dotyczących indywidualnych spraw doktorantów, aczkolwiek poważnie utrudniało określenie ewentualnej pozycji procesowej takiego Rzecznika. Biorąc jednak pod uwagę, że postanowienia ówcześnie obowiązującego Statutu KRD przewidywały, iż do jej zadań należy m.in. reprezentowanie środowiska doktorantów wobec organów władzy publicznej, a także propagowanie interesów oraz obrona praw doktorantów, nic nie stało na przeszkodzie, by osoba pełniąca funkcję Rzecznika wspomnianej grupy społeczności akademickiej była jednocześnie pełnomocnikiem KRD powołanym do obrony praw doktorantów ${ }^{19}$. Możliwość taką stwarzał zresztą § 14 ówcześnie obowiązującego Statutu KRD. Funkcjonowanie Rzecznika w takiej formule było jednak zdecydowanie słabsze niż gdyby - jak ma to miejsce obecnie - działał on jako organ KRD, choćby z tego powodu, iż chcąc zaangażować się w określoną sprawę, zobowiązany był przedłożyć stosowne pełnomocnictwo. Natomiast będąc organem, jego legitymacja wynika wprost z postanowień statutowych.

Warto podkreślić, że udział obu omawianych w tym miejscu rzeczników w postępowaniach dotyczących indywidualnych spraw studentów i doktorantów wymaga zgody strony określonego postępowania ${ }^{20}$. Uregulowania przewidziane postanowieniami statutów KRD i PSRP wprowadzają zatem swoisty wyłom w stosunku do przepisów Kodeksu postępowania administracyjnego określających warunki udziału organizacji społecznej w postępowaniu administracyjnym, które takiej zgody nie przewidują. Biorąc jednak pod uwagę, że zarówno KRD, jak i PSRP, a co za tym idzie także będący ich organami rzecznicy praw pełnią służebną rolę wobec członków społeczności akademickiej, których reprezentują, tego rodzaju ograniczenie wydaje się w pełni uzasadnione.

Mocą art. 202 ust. 1 i 2 PrSzkolWyż studenci studiów pierwszego i drugiego stopnia oraz jednolitych studiów magisterskich prowadzonych przez uczelnię tworzą samorząd studencki, a jego organy są wyłącznym reprezentantem ogółu studentów uczelni. Analogiczne rozwiązanie w odniesieniu do doktorantów i ich samorządu przewiduje art. 208 PrSzkolWyż.

Mając na względzie powołany wcześniej pogląd E. Smoktunowicza, za bezsporny należy uznać zrzeszeniowy charakter obu samorządów oraz ich trwałość.

${ }^{18}$ Statut Krajowej Reprezentacji Doktorantów przyjęty uchwałą Zjazdu Delegatów z 4.11.2011 r., www.krd.ogicom.pl/pl/dokumenty/statut.html (dostęp: 19.12.2011).

${ }^{19}$ Możliwość taką przewidywał $§ 14$ Statutu KRD z 2011 r., który określając kompetencje i obowiązki zarządu KRD, wymieniał wśród nich (w punkcie 2) uprawnienie do powoływania (na wniosek przewodniczącego KRD) pełnomocników do wykonywania określonych zadań.

${ }^{20}$ Por. $\S 22$ ust. 4 Statutu KRD z 2014 r. oraz $§ 33$ ust. 4 Statutu PSRP. 
Normatywnym wyrazem tej tezy jest fakt, iż każdy student lub doktorant danej uczelni ex lege staje się członkiem odpowiedniego samorządu i swego członkostwa nie może się zrzec. Jednocześnie prawo nie dopuszcza możliwości wstąpienia w szeregi samorządu osób „z zewnątrz”21. Oba rodzaje samorządów, podobnie jak wcześniej PSRP i KRD, spełniają wymóg funkcjonowania poza strukturą aparatu państwowego, rozumiany przede wszystkim jako brak podległości organizacyjnej instytucjom tego aparatu ${ }^{22}$, niekoniecznie zaś brak zależności w aspekcie finansowym ${ }^{23}$. Ostatecznie można więc przyjąć, że zarówno samorząd studencki, jak i samorząd doktorantów są organizacjami społecznymi w rozumieniu art. 31 $\S 1-3 \mathrm{KPA}$, a zatem mogą występować w omawianych kategoriach spraw jako podmiot na prawach strony.

Posiadanie przez dany podmiot statusu organizacji społecznej wiąże się z określonymi w art. $31 \S 1-3 \mathrm{KPA}$ uprawnieniami procesowymi w postaci występowania z żądaniem wszczęcia postępowania bądź dopuszczenia do udziału w już toczącym się postępowaniu dotyczącym innej osoby. Zadośćuczynienie takiemu żądaniu skutkuje przyznaniem organizacji statusu podmiotu na prawach strony, który choć nie posiada wówczas legitymacji procesowej, gdyż postępowanie dotyczy cudzej sprawy, to korzysta z uprawnień procesowych ze skutkiem identycznym, jakby określoną czynność dokonała bezpośrednio strona $^{24}$.

Organizacja społeczna, która w postępowaniu nie uczestniczy na prawach strony, może natomiast, za zgodą organu administracji publicznej, przedstawić swój pogląd w sprawie, wyrażony w uchwale lub oświadczeniu jej statutowego organu (art. $31 \S 5 \mathrm{KPA}$ ). Jeśli jednak chciałaby działać w charakterze uczestnika na prawach strony, wówczas zgodnie z art. $31 \S 1$ KPA ciąży na niej obowiązek wykazania celu uzasadniającego jej udział w postępowaniu oraz przemawiającego za takim udziałem interesu społecznego.

Ustawodawca nie sprecyzował pojęcia interesu społecznego, uznając najwyraźniej potrzebę jego dekodowania przez pryzmat konkretnej sprawy ${ }^{25}$. Cel natomiast musi mieć statutowy charakter, a ponadto powinien być trwały, stano-

${ }^{21}$ Por. R. Szarek, Glosa do uchwaty sktadu siedmiu sędziów SN z dnia 10.02.2000 r., III CZP 29/99, „Przegląd Sądowy” 2001, nr 5, s. 134-135.

${ }^{22}$ Por. R. Suwaj, Praktyczne aspekty udziału organizacji społecznych w ogólnym postępowaniu administracyjnym, „Samorząd Terytorialny” 2010, nr 1-2, s. 40-41.

${ }^{23}$ Należy pamiętać, że zgodnie z przepisami PrSzkolWyż środki na funkcjonowanie PSRP i KRD przekazuje minister właściwy ds. szkolnictwa wyższego, natomiast fundusze na działalność samorządów musi zapewnić uczelnia. Siłą rzeczy można więc mówić o występowaniu zależności natury finansowej, której jednak nie należy interpretować w kategoriach podporządkowania organizacyjnego, związanego z wydawaniem ściśle określonych poleceń służbowych.

${ }^{24}$ W. Chróścielewski, [w:] W. Chróścielewski, J. P. Tarno, Postępowanie administracyjne i postępowanie przed sąami administracyjnymi, Lexis Nexis, Warszawa 2013, s. 86.

${ }_{25}$ J. Chmielewski, Glosa do wyroku NSA z 24.06. 2009 r., II OSK 1038/08, OSP 2011, nr 6, poz. 70 , s. 471 . 
wiąc sedno działalności danej organizacji ${ }^{26}$. Tym samym musi być też związany z przedmiotem konkretnej sprawy zarówno w sensie faktycznym, jak i prawnym ${ }^{27}$. Pojawia się jednak pytanie, czy cel taki można wywodzić z innego aniżeli statut aktu regulującego działanie danej organizacji, jak ma to miejsce m.in. w przypadku niektórych $\mathrm{z}$ analizowanych $\mathrm{w}$ tym fragmencie opracowania podmiotó $\mathrm{w}^{28}$.

W powyższej kwestii doktryna oraz orzecznictwo postulują, by pojęcie statutu rozumieć szeroko, wykraczając poza ramy interpretacji słownikowej, a więc nie tylko jako nazwany w ten sposób dokument, lecz także każdy akt określający cele, strukturę oraz formy działalności organizacji ${ }^{29}$. Dzięki temu zarówno dysponujące swoimi statutami PSRP i KRD, jak i samorządy: studencki i doktorantów mogą występować w charakterze organizacji społecznej jako podmiot na prawach strony, o ile oczywiście cel wynikający ze statutu bądź regulaminu pozostaje w bezpośredniej relacji z przedmiotem toczącego się postępowania ${ }^{30}$.

Poza wskazaniem wspomnianego celu działania, postanowienia statutu bądź innego aktu stanowiącego jego odpowiednik powinny wskazywać podmiot uprawniony do występowania w imieniu danej organizacji. Potrzebę taką łatwo dostrzec szczególnie w przypadku samorządów studenckiego i doktorantów, tworzonych przez ogół studentów bądź doktorantów danej uczelni ${ }^{31}$. Podmioty te nie mogą jednak działać w postępowaniu jako tak wyjątkowo liczny kolektyw, dlatego zasadne jest, by akt regulujący ich funkcjonowanie określał kwestię reprezentacji danego samorządu w analizowanych sprawach.

Organizacja społeczna niebiorąca udziału w postępowaniu jako podmiot na prawach strony może, w myśl art. 31 § 5 PA, wyrazić swoje stanowisko w określonej sprawie, przedstawiając organowi administracji - za jego zgodą - stosowną uchwałę lub oświadczenia organu statutowego. Nie musi przy tym uzasadniać

${ }^{26}$ Por. G. Łaszczyca, [w:] G. Łaszczyca, Cz. Martysz, A. Matan, Kodeks postępowania administracyjnego. Komentarz, t. 1, Lex a Wolters Kluwer business, Warszawa 2010, s. 411; R. Suwaj, op. cit., s. 40; W. Dawidowicz, Ogólne postępowanie administracyjne. Zarys systemu, Wydawnictwo PWN, Warszawa 1962, s. 82.

${ }^{27}$ A. Gronkiewicz, op. cit., s. 206 i powołane tam orzecznictwo, a także A. Wróbel, [w:] M. Jaśkowska, A. Wróbel, Kodeks postępowania administracyjnego. Komentarz, Wolters Kluwer SA, Warszawa 2009, s. 265.

${ }^{28}$ Samorząd studencki oraz samorząd doktorantów posługują się w tym zakresie regulaminami.

${ }^{29}$ Por. A. Gronkiewicz, op. cit., s. 206 i powołane tam orzecznictwo, a także R. Suwaj, op. cit., s. 49; A. Skoczylas, M. Swora, op. cit., s. 31-32.

${ }^{30}$ Analiza tego rodzaju aktów wyraźnie wskazuje, iż w sposób dość ogólny określają one zadania danej organizacji. Generalnie zamykają się one w stwierdzeniach poświęconych obronie praw studentów lub doktorantów, czy prowadzeniu działalności w zakresie spraw osób tworzących powyższe grupy społeczności akademickiej. W efekcie bez trudu można sobie wyobrazić udział przywoływanych już wielokrotnie podmiotów nie tylko w sprawach dotyczących skreślenia $\mathrm{z}$ odpowiedniej listy, lecz także w postępowaniach rozstrzygających, np. sprawy pomocy materialnej.

${ }^{31}$ Por. art. 202 ust. 1 oraz 208 ust. 1 PrSzkolWyż. 
swojej aktywności ani celem statutowym, ani interesem społecznym ${ }^{32}$. Wydaje się jednak, że uzyskanie wspomnianej zgody w przypadku omawianych organizacji studenckich i doktoranckich byłoby przesadnym rygoryzmem. Przepisy PrSzkolWyż wyraźnie czynią przecież organy samorządów danej uczelni reprezentantem ogółu ich członków, zaś PSRP i KRD reprezentantem odpowiednio ogółu studentów i doktorantów w kraju, określając w pewnym sensie relacje między tymi podmiotami a organami uczelni ${ }^{33}$. Nie zaburza to zresztą funkcjonowania tych organów, gdyż nie są one związane treścią przedstawionego stanowiska. Pod jego wpływem mogą jednak zmienić optykę patrzenia na sprawę, rozstrzygając ostatecznie odmiennie niż pierwotnie zamierzały.

Z kolei forma uchwały albo oświadczenia organu statutowego może być, w zależności od specyfiki sprawy, zastąpiona np. stanowiskiem przedstawiciela organu organizacji wyrażonym tak pisemnie, jak i ustnie do protokołu. Wydaje się nawet, że organy uczelni niejednokrotnie same zabiegają o taką aktywność, stwarzając przedstawicielom samorządu studenckiego możliwość uczestniczenia w przebiegu egzaminu komisyjnego w roli obserwatora ${ }^{34}$. Czasami także przewidują prawo opiniowania przez niego wniosków dotyczących ulg w opłatach za studia.

Funkcjonowanie na gruncie aktów normatywnych uczelni wyższych rozwiązań podobnych do wyżej przedstawionych każe zastanowić się nad charakterem prawnym udziału samorządów w procesach decyzyjnych związanych ze sprawami studentów i doktorantów.

Pod rozwagę można brać dwie koncepcje, z których jedną - odwołującą się do instytucji współdziałania przy wydawaniu decyzji w rozumieniu art. $106 \mathrm{KPA}$ - należy z góry odrzucić. Ten rodzaj relacji odnosi się bowiem tylko do relacji dwóch organów administracji, a takimi na pewno nie są jakiekolwiek organy samorządów.

Trafniejsza wydaje się koncepcja polegająca na uznaniu, że udział przedstawiciela samorządu w egzaminach komisyjnych bądź w procesie opiniowania wniosków o ulgi w opłatach za studia jest realizacją odpowiedniego zastosowania normy zawartej w art. $31 \S 4$ KPA. Zgodnie z nią obowiązkiem organu administracji wszczynającego postępowanie w sprawie dotyczącej innej osoby (w tym przypadku studenta lub doktoranta) jest zawiadomienie o tym fakcie organizacji społecznej (organu samorządu), jeżeli może być ona zainteresowana udziałem w tymże postępowaniu $\mathrm{z}$ uwagi na swoje cele statutowe oraz przemawia za tym interes społeczny. W tym kontekście można nawet przyjąć, że jeśli obowiązujące w uczelni akty prawne przewidują udział w określonych sprawach organów samorządów lub ich przedstawicieli, to z góry przesądzono o ich zainteresowaniu, a priori zakładając zbieżność tych spraw z celami statutowymi (regulaminowymi) oraz interesem społecznym.

32 A. Gronkiewicz, op. cit., s. 208.

${ }_{33}$ Por. art. 202 ust. 2, art. 208 ust. 1, art. 203 ust. 1 i 2 oraz art. 209 ust. 3 PrSzkolWyż.

34 Por. § 39 ust. 2 Regulaminu studiów w UŁ przyjętego uchwałą nr 310 Senatu UŁ z dnia 4 kwietnia 2011 r. ze zm. 
Podsumowując, można skonstatować, że zarówno studenci, jak i doktoranci mogą liczyć na silne wsparcie zrzeszających je samorządów oraz innych podmiotów działających na ich rzecz. Co ważne, wsparcie to nie jest iluzoryczne, lecz ma podstawę w przepisach procesowego prawa administracyjnego, pozwalając realnie oddziaływać na bieg postępowań administracyjnych prowadzonych w indywidualnych sprawach studentów i doktorantów. Mimo to wypada zauważyć, że świadomość tego faktu jest wciąż stosunkowo niska zarówno wśród władz szkół wyższych, studentów oraz doktorantów, jak i podmiotów, których działalność była głównym przedmiotem rozważań niniejszego opracowania. Nic przy tym nie wskazuje na zmianę tego stanu rzeczy w najbliższej przyszłości, wskutek czego wciąż wielu studentów i doktorantów będzie musiało samodzielnie zmagać się z problemami w relacjach z władzami uczelni, mimo że aktualnie obowiązujące uregulowania powołują do życia instytucje oraz stwarzają odpowiednie mechanizmy ich funkcjonowania pozwalające skuteczniej dbać o prawa i interesy wspomnianych wyżej osób.

\section{BIBLIOGRAFIA}

Adamiak Barbara, Borkowski Janusz. 2014. Postepowanie administracyjne i sądowoadministracyjne. Warszawa: Wolters Kluwer.

Bąkowski Tomasz. 2007. „Glosa do uchwały NSA z 12.12.2005 r., II OPS 4/05”. Gdańskie Studia Prawnicze - Przegląd Orzecznictwa 2: 53-60.

Brzezicki Tomasz. 2010. Ustrój szkolnictwa wyższego w Polsce, Toruń: Wydawnictwo „Dom Organizatora".

Chmielewski Jan. 2011. „Glosa do wyroku NSA z 24.06. 2009 r., II OSK 1038/08”. OSP 6.

Chróścielewski Wojciech, Tarno Jan. 2013. Postępowanie administracyjne i postępowanie przed sądami administracyjnymi. Warszawa: Lexis Nexis.

Daszkiewicz Marta. 2008. „Uwagi na tle udziału prokuratora w postępowaniu przed organem II instancji”. Administracja. Teoria-Dydaktyka-Praktyka 4.

Dawidowicz Wacław. 1962. Ogólne postępowanie administracyjne. Zarys systemu, Warszawa: Wydawnictwo PWN.

Gronkiewicz Anna. 2010. Kilka uwag na temat udziału organizacji społecznej (pozarządowej) w postępowaniu administracyjnym i postępowaniu sądowoadministracyjnym. W Kodyfikacja postępowania administracyjnego na 50-lecie k.p.a. Red. Niczyporuk Janusz. Lublin: Wydawnictwo WSPA.

Gronkiewicz Anna. 2012. Organizacja społeczna w ogólnym postępowaniu administracyjnym. Warszawa: Lex a Wolters Kluwer business.

Grzeszczuk Marta. 2010. Z problematyki form udziału organizacji społecznych w postępowaniu administracyjnym. W Kodyfikacja postepowania administracyjnego na 50-lecie k.p.a. Red. Niczyporuk Janusz. Lublin: Wydawnictwo WSPA.

Jaśkowska Małgorzata, Wróbel Andrzej. 2009. Kodeks postępowania administracyjnego. Komentarz. Warszawa: Wolters Kluwer SA.

Kodeks postępowania administracyjnego. Komentarz. 2011. Red. Wierzbowski Marek, Wiktorowska Aleksandra. Warszawa: C.H. Beck. 
Łaszczyca Grzegorz, Martysz Czesław, Matan Andrzej. 2010. Kodeks postępowania administracyjnego. Komentarz, t. I. Warszawa: Lex a Wolters Kluwer business.

Repela Józef. 2006. „Glosa do uchwały NSA z 12.12.2005 r., II OPS 4/05”. ZNSA 1.

Skoczylas Andrzej, Sfora Mariusz. 2006. „Organizacje społeczne (pozarządowe) w postępowaniu administracyjnym i sądowoadministracyjnym”. Administracja. Teoria - Dydaktyka-Praktyka 3.

Skrzydło-Niżnik Iwona. 2006. „Glosa do uchwały NSA z 12.12.2005 r., II OPS 4/05”. Przegląd Sejmowy 2.

Smoktunowicz Eugeniusz. 1970. Analogia w prawie administracyjnym. Warszawa: Państwowe Wydawnictwo Naukowe.

Smoktunowicz Eugeniusz. 2004. Udział organizacji społecznej w postępowaniu administracyjnym dotyczącym innej osoby (art. 31 k.p.a.). W Procedura administracyjna wobec wyzwań wspótczesności. Red. Duniewska Zofia, Górski Marek, Stahl Małgorzata. Łódź: Wydawnictwo Uniwersytetu Łódzkiego.

Suwaj Robert. 2010. „Praktyczne aspekty udziału organizacji społecznych w ogólnym postępowaniu administracyjnym”. Samorzad Terytorialny 1-2.

Szarek Ryszard. 2001. „Glosa do uchwały składu siedmiu sędziów SN z dnia 10.02.2000 r., III CZP 29/99". Przegląd Sądowy 5.

Tarno Jan. 2006. „Glosa do uchwały NSA z 12.12.2005 r., II OPS 4/05”. ZNSA 1.

Waltoś Stanisław, Rozmus Andrzej. 2009. Szkolnictwo wyższe w Polsce. Ustrój-prawo - organizacja. Rzeszów: Wydawnictwo Wyższej Szkoły Informatyki i Zarządzania z siedzibą w Rzeszowie.

Zieliński Adam. 2006. „Glosa do uchwały NSA z 12.12.2005 r., II OPS 4/05”. PiP 8.

\section{Paweł Dańczak}

\section{SELECTED ASPECTS OF PARTICIPATION OF A COMMUNITY ORGANIZATION IN PROCEEDINGS CONCERNING INDIVIDUAL CASES OF STUDENTS AND POSTGRADUATES}

\footnotetext{
Abstract. The purpose of this paper is to present an in-depth analysis of the participation of a community organization in administrative proceedings concerned with students and postgraduates' matters. Deliberations conducted in this paper have been limited to strictly selected and described in its content entities. Their selection was determined by the specificity of student-postgraduate affairs and the whole sphere of higher education. This includes an explanation of the legal nature of those entities, their procedural rights, which have their origin in the regulations of the administrative procedure which in these particular categories of cases will apply mutatis mutandis.

Keywords: administrative procedure, higher education, matters of students and postgraduates, community organization, students and postgraduates' council, ombudsmen of students and postgraduates' rights.
} 